\title{
Selected Reference Books of 1975-76
}

$\mathrm{T}$ al series originally edited by Constance M. Winchell. Although it appears under a byline, the list is actually a project of the Reference Department of the Columbia University Libraries, and notes are signed with the initials of the individual staff members. ${ }^{1}$

Since the purpose of the list is to present a selection of recent scholarly and general works of interest to reference workers in university libraries, it does not pretend to be either well balanced or comprehensive. A brief roundup of new editions of standard works, continuations, and supplements is presented at the end of the column. Code numbers (such as DE47, 2AA82) have been used to refer to titles in the Guide to Reference Books and its supplements. ${ }^{2}$

\section{BIBLIOGRAPHY}

Allworth, Edward. Soviet Asia: Bibliographies; a Compilation of Social Science and Humanities Sources on the Iranian, Mongolian, and Turkic Nationalities, with an Essay on the Soviet-Asian Controversy. (Praeger Special Studies in International Politics and Government) New York, Praeger, 1975. 686p. \$35. 73-9061.

"This bibliography of bibliographies aims

1. Patricia Ann Clark, Diane Goon, Rita Keckeissen, Anita Lowry, Eileen Mcllvaine, Doris Ann Sweet, Barbara Wendell; Lehman Library: Mary Ann Miller.

2. Constance M. Winchell, Guide to Reference Books (8th ed.; Chicago: American Library Assn., 1967); Supplement I (Chicago: American Library Assn., 1968); Supplement II (Chicago: American Library Assn., 1970); Supplement III (Chicago: American Library Assn., 1972). to present bibliographies in the humanities and social sciences, published in the Czarist Empire and its Soviet successor, and pertaining directly to the Iranian, Mongolian, and Turkic nationalities and the regions of Czarist Russia and the USSR associated with them" (Introduction). To accomplish his purpose, Professor Allworth has systematically gleaned sources dating from 1850 to 1970 , mainly separately published lists of bibliographies and bibliographies of bibliographies appearing as serials, but including also encyclopedias, journals, and some Western-language guides. These are listed and described in the introductory essay, "Sources and Methods for the Bibliography," which also offers a concise discussion of the state of the art.

The body of the work is arranged first by the five main regions of the Czarist or Soviet East, then by five smaller territories and twenty-eight nationalities. Entries within each section are classed according to ten subject categories, and each is annotated as to languages of the entries and the text, number of entries, period covered, etc. Annotations are not evaluative, nor for those titles unverified by location in the Columbia University Libraries, necessarily complete. There is no index.

This is an exemplary work and a pioneering one which should indeed inspire "someone [to $_{\text {] }}$ prepare a list of bibliographies for the other Soviet Nationalities"-Professor Allworth's hope and, no doubt, that of many scholars and librarians.-M.A.M.

Philippine Union Catalog. Jan./Mar. 1974. Quezon City, Univ. of the Philippines Library, 1974- . 3 quarterly issues plus annuảl cumulation.

Serving the double purpose of national bibliography and national union catalog for Philippine materials, this new series supersedes the Philippine Bibliography, 1963-72 
(Suppl. 2AA82); the 1973 gap will be filled upon publication of a Filipiniana Union Catalog, 1968-73, which is in preparation. An author listing with title and subject indexes, the catalog gives complete bibliographic citations for "Filipiniana materials including books, theses, music scores, phono-discs, tapes, microfilms, new serial titles and other materials, or reproductions of any of these forms. It also includes government documents and publications except individual acts, bills and ordinances" (Introduction). Both current materials and older works recently acquired at cooperating libraries are listed. In addition to the University of the Philippines Library and its many departments and branches, three other libraries are represented in the early issues, and the cooperation of other institutions is encouraged.-E.S.

\section{Book Reviews}

Current Book Review Citations. v.1- , Jan. 1976- . Bronx, New York, H. W. Wilson Co., 1976- . Monthly (except Aug.), with annual cumulation. $\$ 75$ a yr.

The "spin-off" has become a familiar aspect of the reference book field, and matters of price, rearrangement of subject matter, ease of use, etc., in relation to the parent work all weigh heavily in the acquisitions decision. While Current Book Review Citations may be regarded as a kind of spin-off, it is an "augmented" one: it not only brings together the book review citations from all the other Wilson indexes, but adds references to all reviews appearing in the Booklist, Choice, School Library Journal, and Library Journal. Thus, the field covered is reviews of "fiction and non-fiction, including science, law, children's and young adult titles" appearing in more than 1,000 periodicals - "the major literary, educational, and other general and specialized publications"-Pref. Note. Quite apart from the advantage of being able to confine one's search to a single compilation (and only the large general collections will have all of the Wilson indexes together on their shelves), problems posed by interdisciplinary topics and peripheral interests are obviated. An author (or other main entry) listing gives the full review citation, includ- ing the reviewer's name when known; this is followed by a title index. The full list of periodicals, with addresses and subscription prices, appears in the January issue only.

With its broad coverage and frequency of publication, CBRC offers real competition to the Book Review Index (Guide AA $314 a)$, although there are certain variations in the lists of journals covered.-E.S.

\section{Dictionaries}

Latham, Ronald Edward. Dictionary of Medieval Latin from British Sources. Prep. under the direction of a committee appointed by the British Academy. London, Publ. for the British Academy by Oxford Univ. Pr., 1975- . Fasc.1- .

(In progress)

Contents: Fasc.1, A-B. \$44.50.

Based on sources ranging from c550 to 1586, this important national dictionary "designed to present a comprehensive picture of the Latin language current in Britain from the sixth century to the sixteenth" covers: classical Latin as used by British authors; words and usages of postclassical Latin; and, with fullest treatment, words and usages distinctively British. Vernacular terms are excluded, as are personal and place-names. Layout of entries is similar to that of the Oxford Latin Dictionary (Suppl. 2AE63), but with considerably longer quotations, because medieval sources are much less accessible than classical Latin texts. Words are grouped under key word spelled according to standard classical Latin. Given for each are: English definition, indication of etymology, and a number of quotations (dated and with exact reference) selected to illustrate earliest known usage if nonclassical, and range of usage "not only in time but, where appropriate, over different districts ... types of sources ... forms ... . grammatical and semantic contexts" (p.xiii). The bibliography of sources for the complete Dictionary and a list of abbreviations and signs appear in this first fascicle. The preface recounts the long history of this great scholarly undertaking, and "a note on editorial method" states with clarity the scope, principles, arrangement, etc. A threecolumn page with a variety of typeface makes for a pleasing, readable text.-R.K. 


\section{BIOGRAPHY}

Biographical Dictionaries Master Index. Ed. 1- , 1975/76- . Detroit, Gale Research Co., 1975- . Biennial. (Ed.1: 3v., \$65) 75-19059.

With the publication of this index the publisher has endeavored to reduce, if not eliminate, the frustration often experienced by librarians and library users while searching for current biographical information. Aided by computer technology, the editors have indexed over fifty biographical directories covering a wide range of professions and geographical areas, and including nine of the eleven titles indexed in the Marquis Index to All Books, 1975. The majority of directories indexed include references to living persons only.

A BDMI entry consists of the biographee's name and birthdate plus a code for the biographical directory in which a sketch may be found. A full explanation of the codes (title and edition information) appears in the prefatory matter in v.1, and the title codes are printed on the end papers in each volume. One would prefer that full information about the codes had been printed in each volume, since coded information about editions of certain titles is not readily understandable. Because entries have been drawn from so many publications and no attempt has been made to standardize them, a biographee may be listed in a number of ways. Names with prefixes and suffixes, compound surnames, names which may be written in direct or inverted order, and names which have been transliterated into the roman alphabet may be listed under any or all of the possible variations. Multiple listings allow the most convenient source to be chosen and, when several sources are available, comparison of the sketches can be made. However, repetition of the biographee's name for each source directory listing neither adds to the utility nor enhances the readability of BDMI.

The introduction seems to indicate that each succeeding edition of $B D M I$ will contain an entry for every biographee in this first edition. Thus, those who do not appear in updated editions of the source directories will continue to be listed in new editions of $B D M I$ with reference to the old edition of the source. One would assume that, at some point, paper costs and an ever-expanding list of biographees will warrant publication of retrospective editions or supplements rather than wholly new editions. $-B . W$.

Who's Who among Black Americans. Ed. 1- , 1975/76- . Northbrook, Ill., Who's Who Among Black Americans, Inc., 1976- . \$35.

This new biographical dictionary lists some 10,000 living black Americans selected for inclusion on the basis of "position of responsibility held" and "the level of significant achievement attained in a career of meritorious activity" ( $p . x v)$. The fields of government, business, education, religion, journalism, law, the arts, civil rights, sports, science, etc., are all represented in biographical sketches supplied chiefly by the individuals listed. The few accounts written by staff members are marked with an asterisk. Entries are of the "who's who" type, are in alphabetic order, and include name, occupation, place and date of birth, education, marital status, names of spouse and children, past and present positions held, memberships, military service, and address. A list of abbreviations is given, and there are indexes by geographical location and by occupation. No schedule of publication is mentioned, but presumably, future editions will be issued.- R.K.

\section{Periodicals}

\section{Edgar, Neal L. A History and Bibliography}

of American Magazines, 1810-1820. Metuchen, N.J., Scarecrow, 1975. 379p. \$15. 75-11882.

This work collates, from the magazines themselves and from standard sources like Brigham and Mott, bibliographical and historical information for more than two hundred publications issued in a period for which careful bibliographies are. often lacking. The search lays a few ghosts and notes some corrections to ULS listings.

Titles are arranged alphabetically and include: all title changes, place, publisher, printer, type (i.e., interest or coverage), frequency, price, size, period of publication, availability in the "American Periodical Series" microfilm collection or in a library, 
whether indexed, and (sometimes) reference to a significant book or article concerning the magazine. "Remarks" on the history and character of the journal conclude the entry. There is an appendix of titles excluded, which gives brief bibliographical information; a chronological list of the titles by beginning date; a register of printers, publishers, editors, and engravers; and an introduction on the history of the American magazine. Readers should be aware that the book was completed in 1965 although published in 1975.-R.K.

French Periodical Index, 1973/74- . Westwood, Mass., Faxon, 1976- . Annual. (v.1: 606p.; \$28) (Useful reference ser., 106) $75-28989$.

Comp. by Jean-Pierre Ponchie.

Preface and table of contents in English and French.

Although it may not be the dream-cometrue that the title suggests, this new index should prove a useful complement to more comprehensive indexes such as the IBZ (Guide AF118) or a convenient alternate choice for smaller libraries with limited foreign-language periodical collections. Intended as a guide to "up-to-date information concerning contemporary France" (Pref.) and meant particularly for student use, the 1973-74 volume indexes only seven periodicals: L'Express (overseas edition), Le français dans le monde, Le nouvel observateur, Paris-match, Realités, Sondages and Le monde hebdomadaire (1974 issues only). Maclean's, Jeune Afrique, and Le monde de l'éducation are to be added in the 1975 volume (due "late summer" 1976). Indexing is under twenty-six subject headings (arranged alphabetically according to the French form of the heading) roughly corresponding to the categories used in popular weekly news magazines (e.g., business and economy, food, art, entertainment, environment, armed forces, medicine and health, religion, sports). Within categories the listing is chronological (except that the "people" section is alphabetical by name); titles are usually as they appear in the original publication. Articles of at least a column or more are indexed.-E.S.

\section{LITERATURE}

Logan, Terence P. and Smith, Denzell S. The Popular School; a Survey and Bibliography of Recent Studies in English Renaissance Drama. Lincoln, Univ. of Nebraska Pr., [1975]. 299p. \$15. 7481364.

Similar to the various "reviews of research and criticism" published for the Modern Language Association of America (e.g., Frank Jordan's English Romantic Poets), this is the second volume in a new series "which in its entirety will provide a detailed account of both the historical development and current state of scholarship on playwrights and plays from 1580 to 1642, exclusive of Shakespeare"-Pref. (The preceding volume is Logan and Smith's The Predecessors of Shakespeare, published 1973; a third volume will consider The New Intellectuals.) The present work is devoted to "dramatists who wrote primarily for the open-air public theaters, and anonymous plays first performed in such theaters." Scholars have contributed chapters on Thomas Dekker, Thomas Middleton, John Webster, Thomas Heywood, Anthony Munday, Michael Drayton, and the anonymous plays. A final chapter takes the form of an annotated bibliography on "Other Dramatists." The general pattern of the essays is to first present biographical and general works; then a discussion of criticisms of individual plays; and finally a section on the canon, giving attention to chronology of the plays, standard editions, apocryphal and nondramatic works, and textual studies. There are separate indexes of personal names and of play titles.-E.S.

\section{Motion Pictures}

Bowles, Stephen E. Index to Critical Film

Reviews in British and American Film

Periodicals, Together with: Index to Critical Reviews of Books about Film, 1930-

1972. New York, B. Franklin, [1974].

3v. in 2. \$29.50. 74-12109.

From approximately forty-two years of English-language writings on the film, Bowles has gleaned over 20,000 film reviews and more than 6,000 book reviews. $\mathrm{He}$ has attempted a fairly comprehensive rather than a selective or evaluative list of 
reviews, indexing twenty-seven major film journals (both current and defunct) as well as several other important review sources such as Filmfacts and the International Film Guide. Film reviews vary considerably in quality, but remain, as Bowles points out in his introduction, a potentially useful source of information and/or analysis; and, of course, the critical work of many important film scholars and artists is represented in the reviews indexed here.

The film reviews are listed under the film title most commonly used by the reviewers, with cross-references from alternate titles; most of the review citations indicate reviewer's name (when known), length of review, and extent of the credits provided in the review. Similar types of information-i.e., reviewer, length, amount of publication information-are given for the book review citations, which are arranged by title in a separate section. Diverse approaches to this material are made possible by the five valuable indexes to "Directors," "Film Reviewers," "Authors," "Book Reviewers," and "Subjects of Books about Film."-A.L.

Garbicz, Adam and Klinowski, Jacek. Cinema, the Magic Vehicle; a Guide to Its Achievement. Metuchen, N.J., Scarecrow, 1975- . v.1- . (In progress) 75-2183.

Contents: v.1, Journey One: The Cinema through 1949. 551p. \$18.50.

With the pompous claim that "the idea behind the book is completeness: we have tried to include all films which anyone seriously interested in the cinema would consider worth seeing" (p.xix), the authors announce the scope of this new English-language dictionary of films; later they qualify that statement by excluding most films under sixty minutes long, most documentaries, and "short experimental films"-three groups which certainly contain a number of films "which anyone seriously interested in the cinema would consider worth seeing"! Whatever one makes of such a naive claim to completeness, the facts are that this volume includes the authors' selection of approximately 450 films (my estimate) made throughout the world between 1913 and 1949.
For each film, basic credits and technical information are followed by brief plot summary and commentary, averaging about a page in length. Some major strengths and weaknesses of each film are pointed out, and an effort is made to place it within an appropriate context of other similar films, other films by the same director, historical situation, etc. Arrangement is chronological by year of production, and within years the films are listed in order of "relative quality" (as determined by Garbicz and Klinowski; see p.xx). Titles used are those "most commonly known in English-speaking countries"; an "Index of Films" includes these titles, cross-references from original titles, and titles mentioned in the text but not given separate entries. There is also an index of directors.

Despite considerable overlap with George Sadoul's Dictionary of Films (tr. and updated by Peter Morris, 1972) in selection of films, each work contains a number of films from 1913 to 1949 not found in the other (presumably, future volumes of Cinema will, like Sadoul, cover post1949 cinema). To summarize a few other differences between test dictionaries: In general, Sadoul includes more "minor" films; Sadoul's concise analysis is often supplemented by quotations from directors and other film scholars and by information on remakes and other versions; and, since Sadoul covers more films in less space, his commentary is occasionally less extensive. $-A . L$.

\section{Fine Arts}

Vanderstappen, Harrie A., ed. The T. $L$. Yuan Bibliography of Western Writings on Chinese Art and Archaeology. [London], Mansell, 1975. 606p. $\& 35$.

Begun by Dr. Tung-li Yuan and completed, after his death, by Drs. Vanderstappen and Hsio-Yen Shih, this bibliography was originally conceived as a companion volume to Yuan's China in Western Literature (Guide DE47). The co-editors have expanded it into a comprehensive bibliography listing some 15,000 items. Included are books, exhibition catalogs, and journal articles written in English, German, Dutch, Scandinavian languages, Slavic languages, 
French, and other Romance languages published between 1920 and 1965. Major contributions published before 1920 and China-related materials from Tibet, Mongolia, Japan, and other surrounding areas are also cited.

The bibliography is in two sections. The first is a listing of books and exhibition catalogs; as an added feature, reviews of the books are noted when possible. The second part lists journal articles and special studies. Both sections are arranged by a detailed subject classification devised by Dr. Shih. There is an author index to both sections, plus lists of sources and collectors. The work lives up to the high standards one has come to expect in Mansell publications, but one feature is lacking: an alphabetical subject index. Although one can appreciate the editors' reasons, the omission is still regrettable.-P.A.C.

\section{Foundations}

The Foundation Center Source Book. v.1, 1975/76- . New York, Foundation Center (distr. by Columbia Univ. Pr.), 1975- . Biennial. (v.1: 1034p., \$65) 75-33481.

"Documentation on large grant-making foundations: entity descriptions; policies, programs, application procedures; grants." -Title page.

Designed to relate the needs of fund seekers to the activities of foundations and to assist foundations in making their programs known to a wider public" (Introd.), this new publication will provide a useful complement to the Foundation Directory. It brings together essential, up-to-date information on the larger U.S. foundations operating on a regional or national basis with a view to assisting grant applicants in determining whether a specific proposal falls within the scope of a given foundation's program. Foundations are listed alphabetically, with the following information presented for each: (1) descriptive and fiscal data (based on the entry in the Foundation Directory, revised and updated as necessary); (2) statement of policy, programs, application procedures, etc.; and (3) a listing of recent grants illustrating the current program.-E.S.

\section{SPORTS}

The Oxford Companion to World Sports and Games. Ed. by John Arlott. London, Oxford Univ. Pr., 1975. 1,143p. il. \& 8.50. 75-319716.

Sports and games "which are the subject of national or international competition" are the primary concern of this new "Oxford companion." Board and table games, however, have been omitted, as have "blood sports" (bull-fighting is admitted because it is "a contest as distinct from a hunt" and because of the widespread interest therein). The intention of the articles is to "help the reader to understand a sport when he watches it for the first time. The descriptive section explains how it is played-as distinct from how to play it"-Pref. Detailed rules of each game are not printed, but a digest is provided, together with a diagram of the playing field, etc., as applicable. There are entries for individual sports figures and champions, and for specific sporting events and competitions. Articles are unsigned, but a list of contributors is given; there are occasional bibliographic citations. - E.S.

\section{ETHNOLOGY}

Handbook of Major Soviet Nationalities. Zev Katz, ed. New York, Free Pr. [1975]. 481p. \$25. 74-10458.

"Census statistics indicate that over the seven decades separating the first Russian census from the most recent one, the number of nationalities has tended to diminish as the smaller ethnic groups lost out to major ones closest to them culturally and territorially. .... As a result the nationalities structure of the Soviet Union is becoming streamlined, the minor Soviet Nationalities growing leaner and the major ones fatter" -Introd. The intent of this book, then, is to present for each of the seventeen nationalities in the USSR data and information in three areas: (1) general: economy, history, demography, culture, etc.; (2) media: language data, local and foreign media, educational and cultural institutions; and (3) national attitudes: the factors forming them, views of scholars, and recent manifestations of nationalism. The latter section 
is particularly concerned with the political relationships between the minorities and the Soviet authorities or the "Great Russian Majority."

Each chapter is by a specialist, and each is supplemented by charts and references. There is an appendix of twenty-nine comparative tables giving data on speakers of languages of major nationalities, urbanrural distribution by nationality and republic, national development, sociocultural development, etc. This is a composite reference work offering varied data and fascinating description and analysis-historical, sociological, cultural, and political.-M.A.M.

Hodge, William. A Bibliography of Contemporary North American Indians, Selected and Partially Annotated with Study Guide. New York, Interland, 1976. 296p. \$22.50. 75-21675.

Addressed to professional anthropologists, to those who deal with Indians in an official capacity, and to the interested layperson, this classified bibliography lists almost 2,600 items included for their significant ethnographic content, for their focus on current Indian activity, for their lack of wide circulation, or for the fact of their being unpublished. Examples of this last criterion are stated to be "state and federal reports such as committee hearings, position papers, procedural guides, tribal government documents, etc."-Introd. A "study guide" summarizing the categories used precedes the main bibliography in which entries appear, alphabetic by author, under such topics as social organization, material culture, population dynamics, migration patterns, city living, economics, education, religion, etc. Full bibliographical details are given, and many items are annotated. Entries include books, articles, documents, dissertations, master's essays, conference papers, and museum publications, chiefly from the last fifteen years. There is an index of tribes, states, areas, and regional groupings, but not one of authors. An introductory section, which incorporates recommended background reading, is devoted to Indian life prior to $1875 .-$ R.K.

\section{Political Science}

Cook, Chris. Sources in British Political
History, 1900-1951. Comp. for the British Library of Political and Economic Science. New York, St. Martin's Pr., 1975- .v.1- .75-4012.

Contents: v.1, Guide to the Archives of Selected Organisations and Societies. 330p. $\$ 15.77$.

In 1970 the British Library of Political and Economic Science undertook a survey of contemporary political archives in Great Britain in order to locate, preserve, and identify them for scholarly use. The pilot project resulted in the publication of Cameron Hazlehurst and Christine Woodland's Guide to the Papers of British Cabinet Ministers, 1900-1951 (London, Royal Historical Society, 1974). This new volume is the first of a projected three-volume guide; successive volumes will deal with the papers of selected civil servants and all members of Parliament for the period. The survey was apparently conducted principally in English archives, since three appendixes give only brief notes on relevant archives in Northern Ireland and Eire, Scotland, and Wales. Moreover, since guides to the contents of the Public Record Office exist, no survey was made of collections there. Reference to private papers was made only when no records were found in libraries and archives open to the public.

Political parties, societies, trade unions, pressure groups, and other institutions influential in contemporary British political life are entered alphabetically, with the exception of combined entries for temperance, women's suffrage, syndicalist, and radicalright groups. A brief description of each organization's history and purpose is followed by a survey of its papers (with some indication of printed sources) and information on their location and availability. The text concludes with a list of addresses of libraries and archives, followed by an index to the names of organizations and societies included. The utility of such a guide is obvious, and the high quality established by the Hazlehurst volume has been maintained. Subject and individual name entries in the index would have made this guide even more valuable.-D.G.

Norton, Philip. Dissention in the House of Commons; Intra-Party Dissent in the House of Commons' Division Lobbies,

4

(1) 
1945-1974. [London, Macmillan, 1975] 643p. $\$ 36.93$.

Upon occasion, Wilding's Encyclopaedia of Parliament notes, a vote in the House of Commons "is carried to a division, which is a physical separation into two lobbies of those members wishing to vote for and those wishing to vote against a measure. ... The division lists record the names of the members taking part in a division and the manner of voting, and they constitute an official record which is reproduced in Hansard." Until very recently, political scientists and historians have been more interested in the dissent which takes place within a party before a vote is taken. With this compendium Norton hopes to direct interest toward the "cross-votes and other occasion of intra-party dissent which have taken place in the House of Commons' division lobbies from 1945 to 1974 . . . . In each case, the names of those members who voted against the whip are listed preceded by a short précis of the debate upon which the vote occurred, with particular emphasis upon the views (if any) by those who subsequently cast the dissenting vote [or abstained from voting]"-Introd. The text is extremely well written, providing capsule summaries of some of the major pieces of legislation as well as some of the more frivolous bills. Of great interest is the conclusion, which points up the increase in intra-party dissent, especially from the backbenchers. There is a useful subject index and a members' index.-E.M.

\section{History and Area Studies}

American Studies Bibliography, 1974- . [London, Univ. of London, Institute of United States Studies, 1975- ] Microfiche (negative). Monthly, with annual cumulation. (1976 monthly issues with annual cumulation, £22; annual cumulation only, \&11)

The Institute of United States Studies was founded in 1965 to provide facilities for graduate study leading to the M.A. degree in U.S. area studies at the University of London. As part of this effort, the institute has published directories of educators in the field and lists of theses in progress, and has established a union catalog of
American materials in the University of London libraries. Its newest project is an ongoing bibliography of books on American studies selected from the British National Bibliography and the Library of Congress MARC tapes. Published monthly (and available only in microform) with an annual cumulation, the bibliography lists materials in four sections: author, title, subject, and classified Dewey Decimal system. Complete cataloging information (including subject headings and Library of Congress and Dewey class numbers) is given for each entry. The institute advertises that "all books published anywhere in the world which are relevant to the study of the United States" are included, but an examination of a number of 1974 fiche showed no titles published outside the United States and the United Kingdom; similarly, all titles were English-language works. The 1974 annual cumulation listed 20,000 books (some published with earlier imprints) and covered a wide variety of formats (e.g., government documents and thesis reprints) and types (fiction and poetry are included, but juvenile literature and periodicals are not).

The fiche are computer-generated, negative-image, standard four by six inches, with $24 \times$ reduction ratio. Each fiche is clearly marked at the top with date, section, and contents; an index to the contents of each appears in the lower right-hand corner. Legibility is good. American Studies Bibliography can be ordered as monthly issues with annual cumulation, or as an annual cumulation only; individual sections may also be ordered separately. According to information from the institute, the 1975 annual should now be available; inasmuch as this review was based on the 1974 annual cumulation without access to the most recent monthly issues, the time lag for current coverage cannot be indicated.-D.G.

Atiyeh, George Nicholas. The Contemporary Middle East, 1948-1973; a Selective and Annotated Bibliography. Boston, G. K. Hall, 1975. 664p. \$49. 74-19247.

The basic European-language literature on the history, politics, social conditions, education, and economic conditions of the Middle East, the Maghrib (North Africa), 
Turkey, and Iran is arranged by geographical area and by country in this extensive bibliography. Some Arabic, Turkish, and Persian works are included if necessary for complete coverage; works on Israel are included only as they bear on the Arab-Israeli conflict (for which there is a special section); and a section on arts and letters lists items chosen for social and political relevance rather than for "intrinsic literary or artistic value."

Monographs and journal articles of the period 1948-73 plus a small number of pamphlets are listed. The short annotations are mainly descriptive; they sometimes state the author's conclusions or term a work "scholarly," "informative," "sensitive," etc. The index is essential for its cross-references from variant spellings of names to the Library of Congress form used in the entries, and for access to entries which may seem misplaced (e.g., an item on slavery under "general works" or one on food and inflation under "history"). All told, however, this is a useful tool for students of the contemporary Middle East and for the beginning researcher.-M.A.M.

\section{A Bibliography of English History to 1485:}

Based on the Sources and Literature of English History from the Earliest Times to about 1485 by Charles Gross. Ed. by Edgar B. Graves. Oxford, Clarendon Pr., 1975. 1103p. \&20. 76-355448.

Issued under the sponsorship of the Royal Historical Society, the American Historical Association, and the Mediaeval Academy of America.

Librarians and researchers can be very pleased that Gross' Sources and Literature of British History . . . (2d ed., 1915; Guide DC119) has been so thoroughly revised and updated. Professor Graves and his committee of scholars have remained faithful to the purpose of Gross, emphasizing source material "and direct commentaries thereon, older standard or seminal studies in books and articles, and recent writings, especially those which set forth new or controversial interpretations or include modern specialized bibliographies, ... . and auxiliaries to the study of history and the aids to historical research"-Pref.
The bibliography concentrates on English history from Roman times up to the beginning of the Tudor period when Conyers Read's Bibliography of British History, Tudor Period (2d ed., 1959; Guide DC110) commences. "Like the previous editions, it includes for the pre-Norman period some fundamental studies on Welsh and Irish history; but it comprises for the period from 1066 to 1485 only those studies about nonEnglish areas which relate directly to England. . . . No attempt has been made to include Scottish history." Format remains much the same, but the arrangement has changed from a primarily chronological presentation to a more topical one. Some of the section headings reflect the shift of interest toward economic and cultural history: e.g., urban society; intellectual interests; agrarian society; special jurisdictions (which include sections on forests, the Palatinates, and the Jews); scholars, mystics, and their works. Availability of reprint or microform editions is indicated, but one wishes that the compiler had also noted the existence of pertinent microform series (e.g., the titles cited in Pollard and Redgrave's Short Title Catalogue, or the "Rolls series") or had pointed out that the Public Record Office and the Bibliothèque $\mathrm{Na}$ tionale have issued lists of their collections which may be purchased on microfilm.

As long as one is carping, one wishes that Appendix D of Gross, "Chronological Tables of the Principal Sources," had been included and updated. Also, there are several bibliographies which could have been added to aid students working in specialized fields-e.g., the Crusades bibliographies of Atiya and Mayer, or the Bibliographie internationale de l'humanisme et de la Renaissance. But these are minor complaints, and limited space is a hard taskmaster. The scope, the headnotes, and the annotations, plus the detailed index make this bibliography a joy to use.-E.M.

A Guide to the Sources of United States Military History. Ed. by Robin Higham. Hamden, Conn., Archon Books, 1975. 559p. \$27.50. 75-14455.

Nineteen bibliographical essays on various military topics have been contributed 
by noted scholars for this volume. Following the editor's general introductory essay, each successive chapter deals with a narrow field within the broader scope of the book. While the basic breakdown of topics is chronological (e.g., "The Navy in the Nineteenth Century, 1789-1889), attention is also given to such matters as "Military and Naval Medicine." Civil War coverage was deliberately limited because of the sheer bulk of material and the existence of other guides. Urging the historian to reach beyond traditional manuscript and printed sources, the editor discusses picture sources in his introductory chapter, and P. K. Lundeberg's final essay, "Museums as Historical Resources," continues the theme, surveying repositories of artifacts and other nonprint material, noting existing printed guides and catalogs as well as appropriate secondary writings.

Each essay begins with a discussion of general monographs and bibliographies, then proceeds to more discrete subtopics, citing articles and dissertations as well as books. Attention is given to archival sources and their printed guides, and suggestions are made regarding areas that need further research. At the end of each chapter is a list of all titles mentioned, with complete bibliographical information.

Although, as one might expect, there is some unevenness and overlap as a result of the composite nature of the work, these weaknesses are outweighed by the advantages of having an expert's appraisal of the field with which he is most familiar. Author, title, and subject indexes would have greatly enhanced the reference value of the work, but unhappily none is included. Nevertheless, anyone contemplating a research project in U.S. military history would be well advised to reach for this volume first. -D.A.S.

\section{New Editions AND Supplements}

The British Library's Subject Index of Modern Books Acquired 1951-1955 (London, British Museum Publs., 1974. 6v.) comprises some 175,000 entries and closes the gap between the $1946 / 50$ and 1956/ 60 volumes of the British Museum's Subject Index (Guide AA68; Suppl. 1AA12). The new compilation employs the more specific forms of subject headings introduced with the 1956-60 volumes. A single index for the $1961-70$ period is in preparation.

"More than 2,600 specialized and professional journals, about 800 of which appear for the first time" (Introd.) are included in the third edition (1975) of the Directory of Publishing Opportunities (Chicago, Marquis Academic Media, 1975 . 850p. $\$ 44.50)$. Entries in this guide for scholars and contributors to professional journals are now arranged under sixty-nine subject fields.

Designed as an ongoing supplement to the Encyclopaedia Universalis (Suppl. 2AD7), a new yearbook entitled Universalia (Paris, Encyclopaedia Universalis, 1974. 196F) has now appeared. The 1974 volume covers "les événements, les hommes, les problèmes en 1973," offering a chronology for the year; a selection of essays on recent developments and problems; a section of alphabetically arranged articles on events, countries, personalities, and special topics; and a section of statistical data.

Fascicle 5 of the Oxford Latin Dictionary (Suppl. 2AE63) has now been published (Oxford, Clarendon Pr., 1976). It covers through the word "pactum" and keeps the work very much on the announced publication schedule of one fascicle every two years. The "second supplemented edition" of Harold Wentworth and Stuart Berg Flexner's Dictionary of American Slang (New York, Thomas Y. Crowell, 1975. 766p. \$12.95) again reprints the basic volume which first appeared in 1960 (Guide AE72) and adds a revised supplement which includes all the material from the 1967 supplement (see Suppl. 2AE9), together with "about 1,500 new slang terms and definitions that have become current since then." The supplement has its own appendix of word lists and selected bibliography.

Entries for approximately 57,000 current periodicals are included in the sixteenth edition of Ulrich's International Periodicals Directory (New York, Bowker, 1975. $2,289$ p. $\$ 50)$. It updates and expands the information in the fifteenth edition and its 1974 supplement, and includes a number 
of new features: e.g., information about microfilm availability; a separate "Index to Publications of International Organizations"; and an "ISSN Index." A three-column page permits the presentation of all this additional information within the single-volume format.

Newspapers in Microform, 1973 (Washington, D.C., Library of Congress, 1975. 208 p. $\$ 11.25$ ) is the first annual supplement to Newspapers in Microform, 19481972. With separate geographical lists for the United States and for foreign countries (plus a combined title index), the annual series supplements both the United States and the Foreign Countries volumes of the parent work. In addition to reporting on new titles, it lists additional library locations for numerous items previously reported.

METRO (New York Metropolitan Reference and Research Library Agency) has published A Union List of Selected Microforms in Libraries in the New York Metropolitan Area as its "Miscellaneous Publication" no.8 (New York, METRO, 1975. 322 p. $\$ 22.50)$. The list not only provides locations for nearly 700 major microform series and unique or unusual items, but includes descriptive notes and references to finding aids or indexes for many of the series.

In the revised edition of the Lutheran Cyclopedia (St. Louis, Concordia Pub. House, 1975. 845p. \$24.95), the number of entries has been increased, various articles have been reworked, new bibliographic references supplied, and a special effort made "to improve objectivity"Pref. Although the previous edition (1954; Guide BB169) was prepared under the auspices of the General Literature Board of the Lutheran Church, this revision does not mention official church sponsorship; cooperation of various church affiliates is noted, however.

The second edition of Contemporary Poets of the English Language (Suppl. 3BD59) is entitled simply Contemporary Poets (London, St. James; New York, St. Martin's, 1975. 1,849p. \$35) and appears under the editorship of James Vinson. Not only have entries from the earlier edition been augmented and updated, but the work represents a somewhat different selection (i.e., some poets have been dropped, and a great many new names have been added). An appendix offers articles on nineteen poets "who have died since 1950 but whose reputations are essentially contemporary."

Frederick Ungar and Lina Mainiero are the editors of a fourth volume of the $E n$ cyclopedia of World Literature in the 20th Century (Suppl. 2BD9). Termed "Supplement and index," the new volume (New York, Ungar, 1975. 462p. il. \$48) is made up largely of biographical/critical sketches of figures (from various decades of the twentieth century, not merely newly established writers) not appearing in v.1-3, but some new topical entries are also included. An analytical index to v.1-4 is also included (p.412-62).

Criticisms have been updated on approximately one-third of the authors included in the original three-volume set of Temple and Tucker's Modern British Literature (Suppl. 1BD42), and forty-nine other writers who have gained critical attention since 1965 have been added in a supplementary volume (designated as v.4 of the set; New York, Ungar, 1975. 650p. \$25), compiled and edited by Martin Tucker and Rita Stein. Bibliographies appearing at the end of the volume also serve to update the basic set.

Three new sections have been added in the third edition of the Guide to Play Selection (Urbana, National Council; New York, Bowker, 1975). 292p. \$5.95) compiled by the NCTE Liaison Committee with the Speech Communication Association and the American Theatre Association: a guide to play production, and separate sections for musical plays and plays by Afro-Americans. A new topical index and a "players index" (arranged by number and sex of players required) are also included. About 850 plays are described. Last appearing in a 1968 edition followed by a 1971 supplement, A. G. S. Enser's Filmed Books and Plays is now available in a new cumulative edition (London, Andre Deutsch, 1975. 549p. \&8.50) covering the period 1928-74.

Ruth W. Gregory is the editor of a third edition of Anniversaries and Holidays (Chi- 
cago, American Library Assn., 1975. 246p. $\$ 10.50$ ), a revision of the 1944 work by Mary E. Hazeltine (Guide CF25). "The total number of entries is 2,736 as compared with 1,764 in the second edition" (Pref.), and covers holidays observed in 152 countries.

Among the changes and revisions to be noted in the "Bicentennial edition" of Richard B. Morris' Encyclopedia of American History (New York, Harper \& Row, 1976. $1,245 \mathrm{p} . \$ 25)$ are the additional coverage for minorities, ethnic groups, and women; the new section for mass media; new subsections for film and dance; and the expansion of the biographical section to include 500 sketches of notable Americans. Supplementary material from the previous edition (Suppl. 1DB6) has been integrated into the body of the work, and the whole is updated through 1973.

New chapters on Finland, Greece, and Luxembourg have been added in the revised and updated edition of Daniel $\mathrm{H}$. Thomas and Lynn M. Case's useful directory (Guide DC3) now entitled The New Guide to the Diplomatic Archives of Western Europe (Philadelphia, Univ. of Pennsylvania Pr., 1975. 441p. $\$ 10$ ). There are also new subsections dealing with the ar- chives of the International Labour Organisation and the International Telecommunication Union. John Merriman Sims is the editor of the 1952-54 volume of Writings on British History (London, Univ. of London, Inst. of Historical Research, 1975. 346p. \&14). It conforms to the scope and arrangement of the preceding volume of the series (1949-51, also published 1975) and, like that volume, includes a "Select list of books published ... on British history since 1939."

What better way to celebrate the nation's Bicentennial than with a new edition of Historical Statistics of the United States? Now subtitled Colonial Times to 1970, this indispensable compilation (Washington, D.C., Govt. Print. Off., 1975. 2v. \$26) has been revised and expanded to present more than 12,500 time series. It includes, with rare exceptions, all the series shown in the 1960 publication and its 1965 supplement (Suppl. 1CG6). The "Bicentennial edition" follows the general plan of the previous edition, though there has been some regrouping of material within chapters. In addition to the increased number of statistical tables presented, a few sections now include some data series below the national level. 


\section{PROGRESS IN BEHAVIOR MODIFICATION, Volume 1}

edited by MICHEL HERSEN, RICHARD M. EISLER, and PETER M. MILLER

". . . The need for review publications to distill the truly significant contributions from the superfluous and present the material in a way that is balanced and thought-provoking is obvious, The editors of this book have set themselves the task of not only providing a review but continuing to do so on an annual basis.

".... All of the authors deserve to be commended for their enthusiasm with regard to their topics and the completeness of their reviews.

"... . One can only hope that the level of excellence demonstrated here can be maintained on an annual basis, as the editors propose."-American Journal of Psychiatry, March 1976
". ... The editors have selected what they considered the best and most recent information on the clinical use of behavior modification and have done a rather commendable job. .... Progress in Behavior Modification is well documented and deserves the attention of the serious student."-Choice, March 1976 Volume 1/1975, 368 pp., \$19.50/£10.70 ISBN: 0-12-535601-2; also available in Library Edition with Microfiche, $\$ 25.00 / £ 13.75$ ISBN: 0-12-535674-9; Microfiche only, $\$ 15.00 / £ 8.25$ ISBN: 0-12-535675-7

Volume 2/1976, 384 pp., $\$ 19.00 / £ 10.45$ ISBN: 0-12-535602-1; also available in Library Edition with Microfiche, $\$ 24.50 / £ 13.50$ ISBN: 0-12-535676-5; Microfiche only, $\$ 14.00 / £ 7.70$ ISBN: 0-12-535677-3

\section{HANDBOOK OF PERCEPTION, Volume 5: SEEING}

\section{edited by EDWARD C. CARTERETTE and MORTON P. FRIEDMAN}

"The fifth of a 10-volume handbook of perception which aims to give a précis of the state of knowledge in every area of perception. ... All the chapters are excellent summaries by the foremost authorities on the areas in question. ... The book is accessible to any student who has had a good course on perception but will prove to be helpful even to the practicing scientist as a critical evaluation of the state of the art and of possible future trends."-Choice, January 1976

Volume 5/1975, 527 pp., \$28.50/£15.70; subscription price, \$24.25 ISBN: 0-12-161905-2

\section{THE SOCIAL PSYCHOLOGY OF BARGAINING AND NEGOTIATION}

by JEFFREY Z. RUBIN and BERT R. BROWN

"This is a very successful effort ... 'to present an extensive overview and analysis of the research in this area [bargaining and negotiation].' The claim to comprehensiveness is fair as the phenomenon of bargaining and negotiation is viewed from the perspective of the issues, social components, physical situation, individual personality differences, and intentional and language characteristics. The bibli- ography is extensive, and an excellent index accompanies the text. ... The clarity of writing and style of organization make the book useful for undergraduate as well as advanced instruction. Overall, this is probably the most valuable single volume on the subject now in print."-Choice, March 1976

1975,359 pp., $\$ 16.50 / £ 9.10$

ISBN: 0-12-601250-4

\section{THE PSYCHOLOGY OF ANIMAL LEARNING}

by N. J. MACKINTOSH

". ... The Psychology of Animal Learning is so impressive both in size and quality that it is likely to be the definitive secondary source in the field for many years.

".... Though his own specialty is discrimination learning, Mackintosh does equally well dealing with other areas, as well as exploring the interrelations among areas. The 619 pages of text and over 1,700 references devoted to this limited range of topics contrast with the 476 pages of text and possibly 1,400 refer- ences that Kimble used to cover a similar range of topics plus motivation, theories of reinforcement, the history of conditioning, and applications to personality. The thoroughness of Mackintosh's coverage of his limited range of topics is thus unlikely ever to be surpassed."-American Journal of Psychology, March 1976

1974,730 pp., $\$ 18.50 / £ 8.00$

ISBN: 0-12-464650-6

N.B.: Postage plus $50 \notin$ handling charge on all orders not accompanied by payment.

Prices are subject to change without notice.

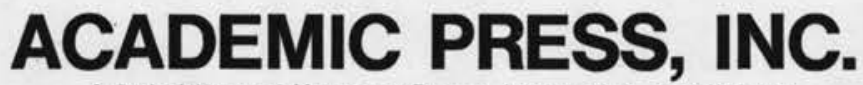

A Subsidiary of Harcourt Brace Jovanovich, Publishers

111 FIFTH AVENUE, NEW YORK, N.Y. 10003 24-28 OVAL ROAD, LONDON NW1 7DX 